\title{
Fostering Environmental Virtue for Children through School Urban Farming in Bandung, Indonesia
}

\author{
Wibowo Heru Prasetiyo \\ Civic Education Department \\ Universitas Muhammadiyah Surakarta \\ Surakarta, Indonesia \\ whp823@ums.ac.id
}

\begin{abstract}
This study aims to describe the impact of a nonformal education programme for children as an attempt to develop their civic virtue in the environmental field. One programme attempted to realise the goal is school urban farming in Bandung. This study used a qualitative method in approaching the programme with the author being actively involved in the programme (participant as observer). The informants were chosen using the purposive sampling technique, while the data were collected by observation, interview, and document analysis. The results showed that school urban farming was effectively able to teach children about ecology and build ecological mentality in their minds. School urban farming was found significant in improving value orientation of the environment, which might be able to generate environmentally significant behaviour. Thus, the programme helped institutionalized civic virtue in the environmental field through learning process.
\end{abstract}

Keywords- civic virtue; environmental behaviour; environmental virtue; school urban farming

\section{INTRODUCTION}

There is a paradox that when many environmental conservation programmes are campaigned, the environmental damage continues. Eenvironmental degradation is a serious problem and considered as global catastrophe since it extends across the territorial sphere of the country [1]. The causes of natural degradation, including biodiversity losses and neverending over-exploitation, is due to humans' misbehaviour in their relationships with nature [2]. This condition contrasted with the nature of human as a creature who has the rights to live in a healthy environment as well as security and health protection [3]. To maintain these ecological human rights, an improvement in interaction pattern between humans and environment is needed.

A widely implemented programme to improve the carrying capacity of environment is urban farming. Most studies about urban farming have been carried out by observing its impacts in various fields. Loram [4] conducted a study on the implementation of urban farming in the United Kingdom which is used as relaxation and recreation area, to secure food logistics, to reserve groundwater, and community socialization. Urban farming community even considered as a social movement in land politicization in urban areas to realise social justice [5]. In contrast, Gallaher [6] argued that urban farming programme in sub-urban cities such as Nairobi, Kenya, is capable for increasing food security and social capital. Carney [7] and Galhena [8] also believed that urban farming activities lead to improved food security, physical and mental health, moreover, doing this activity with family may strengthen family harmony. In addition, the study conducted by Specht [9] mentioned that activities in urban farming can reduce the impact of carbon emissions and increase water and waste recycle.

While studies on urban farming regarding the impacts in health, food and social fields can be easily found, it is also necessary to conduct a study on the impact of urban farming in the field of moral development. Several research on urban farming leading to the development of environmental virtue are also found in several regions. Urban farming programme called Jones Valley Teaching Farm (JVTF) in Birmingham has taught students about farming and gardening, both inside and outside the classroom [10]. The harvests of this programme then being sold at the Farmer's Market Club. This programme has been considered to have influence on the improvement of the $21^{\text {st }}$ Century Skills of communication, marketing, financial literacy, and quality customer service [10]. Additionally, several states in the southern part of USA have been promoting the behaviour of consuming healthy food as well as demonstrating an increase in students' knowledge of agriculture, nutrition, and health through the Farm-to-School Programme [11]. There is also a programme called Urban Farming Youth Internship in Brooklyn, New York, which introduces agricultural practices, time and financial management, cooperation, and public speaking. Participants joining this programme show a progress in terms of responsibility, confidence, and the ability to build strong bond with the surrounding community [12]

Many literatures about implementing school urban farming have not been widely applied in the Asia. Studies in this topic have generally ignored Asia, especially South East Asia, whereas the areas has a wide area of rainforest. For instance, Indonesia has the third largest tropical rainforest, but reduced significantly by deforestation in the last decade [13]. Therefore, this study contributes to enriching the discourse of environmental virtue development. As a model of environmental education, this study shows the potential of children to be developed as individuals who are aware of environmental sustainability. To realize this, children's 
cognitive aspect should be strengthened hence their intelligence to recognize, perceive and think about environmental issues, at least their surrounding, can be a leverage for their ecological morality.

This article is a result of the research conducted in farming community in Bandung, Indonesia. Bandung Berkebun community has a programme called school urban farming that targets children in the school age to understand how to do farming in urban area. Hopefully, by understanding the concept and implementation of urban farming, children may nurture the values of environmental care in themselves. The existence of school urban farming programme in Bandung was motivated by the lack of environmental conservation efforts in the big cities of Indonesia. It was in line with Certoma and Notteboom [14] who pointed out that the environmental programme carried out by the government (top-down) would only work optimally with the support of bottom layers (bottom-up) in the form of social movements. School urban farming programme can be a bottom-up movement of environmental conservation. Through this programme, children have an access to learn gardening and farming in urban area. They will not only gain basic agricultural knowledge, but also the physical process as well as the sense of loving their environment. The output of this programme is not targeted to the environmental carrying capacity, instead, it is emphasized on the internalization of environmental caring valuesfrom an early age. It is due to the importance of fostering ecological consciousness since an early age regarding children's central role as human beings manifested into habits and behaviours. Such consciousness involves positive participation and the ability to access information about environmental activities as the attempt to restore the ecological carrying capacity for life [15].

\section{RESEARCH METHOD}

Qualitative approach was employed in this study with interview and observation that covered several stages. First, the researcher has participated in Bandung Berkebun community, a group of people caring for the environment, for a year. The researcher used participant as observer method in which the observation was carried out through the participation of researcher in all activities [16]. It aimed to build relationships and understanding regarding goals and programmes, particularly, school urban farming. Second, the researcher participated in various activities such as street urban farming, Bandung urban farming market, school urban farming, campus urban farming, and kampung urban farming. Specifically in school urban farming programme, the researcher became facilitator for several schools collaborating with Bandung Urban Farming community to introduce children how to do farming in school environment. Third, the news, photos, and documents of community activities were published to a variety of social media, including Twitter, Instagram, YouTube and website in order to socialise the programme as well as strengthening the analysis.

This study was particularly carried out in the gardens of Bandung Berkebun community in Tubagus Ismail as well as some elementary and kindergarten schools, such as TK Bintang
Ceria, TK Irhamna, SD Semi Palar, SD Pardomuan, SD IT Rabbani, and SDN Raya Barat. Purposive sampling was used as the sampling method considering that the researchers had to ensure that the informants are active members who contribute in the whole activity and have been part of school urban farming activities. This sampling method is particularly useful in interview stage since selected informants understand the structure and process of an individual or given situation [17]. Data collection techniques included interview, observation, and document analysis, while data analysis was performed by interactive analysis models developed by Milles and Hubberman [18].

Theoretically, this study used the perspective of ecological citizenship by Dobson [19]. Dobson's perspective emphasized the linkage of the citizenship status for striving the sustainability of ecosystems in nature in the form of virtue which is not limited to territories [19]. Dobson believes that ecological citizenship is also one view that triggers environmental awareness movement both individually and publicly [19]. This perspective also exceeds environmental citizenship perspective which only focuses on environmental issues without calculating socio-political and economic impacts of the ecological crisis [20]. Therefore, Dobson's perspective will be derived into three aspects of achieving environmental virtue including esnvironmental knowledge, environmental skills, and environmental participation [19].

\section{FINDINGS AND DISCUSSION}

A counselling of school urban farming programme by Bandung Berkebun community is considered as a practice of non-formal education. Non-formal education is defined as an organized and systematic activity conducted independently and adjusted to the learners' need which takes place outside the formal educational institutions such as formal schools [21]. From this definition, school urban farming programme meets the criteria of non-formal education because: (a) the curriculum focuses on the participants; (b) emphasizes practice rather than theory; (c) centred on the community; (d) has flexible programme structure; (e) and has independent programme funding. This programme also demonstrates its support for the integrated community development which is suggested by Sudjana as a characteristic of non-formal education [21]. Furthermore, as non-formal environmental education intended for the wider community through various counselling and trainings, the curriculum structure of this programme is presented in Table 1. 
TABLE I. ENVIRONMENTAL EDUCATION STRATEGY IN SCHOOL URBAN FARMING.

\begin{tabular}{|c|c|c|c|c|c|}
\hline Objective & Source person & Material & Method & Media & Output \\
\hline $\begin{array}{l}\text { - Providing } \\
\text { knowledge on } \\
\text { basic farming } \\
\text { - Improving } \\
\text { farming skills and } \\
\text { maintaining } \\
\text { cleanliness } \\
\text { - Inculcating } \\
\text { ecological } \\
\text { consciousness to } \\
\text { participants }\end{array}$ & $\begin{array}{l}\text { - Members of } \\
\text { Bandung } \\
\text { Berkebun } \\
\text { community } \\
\text { - Agricultural } \\
\text { practitioners }\end{array}$ & 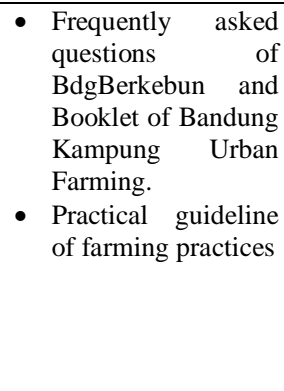 & $\begin{array}{l}\text { - Student oriented } \\
\text { approach and } \\
\text { active learning } \\
\text { - Flexible non- } \\
\text { formal education } \\
\text { without any } \\
\text { obligation of a set } \\
\text { of rigid rules } \\
\text { - Teaching method } \\
\text { by story telling }\end{array}$ & $\begin{array}{l}\text { - The absence of } \\
\text { whiteboard, stationery, } \\
\text { projector or props as } \\
\text { required by formal } \\
\text { school. } \\
\text { - Farming tools such as } \\
\text { pots, seeds, hoes, } \\
\text { shovels, etc } \\
\text { - Props such as posters } \\
\text { and pictures are } \\
\text { occasionally needed to } \\
\text { provide enrichment }\end{array}$ & $\begin{array}{l}\text { - Improvement in students' } \\
\text { awareness of land } \\
\text { management } \\
\text { - Improvement in students } \\
\text { practising basic farming } \\
\text { - Students understand the acts } \\
\text { of environmental crime and } \\
\text { simultaneously support } \\
\text { environmental sustainability } \\
\text { - Students are able to produce } \\
\text { vegetables and fruits which } \\
\text { promotes their self-efficacy }\end{array}$ \\
\hline
\end{tabular}

Based on Table 1, school urban farming programme is a farming educational movement provided for students through workshops utilising simple material and tools as well as unproductive land in the school environment or Bandung Berkebun laboratory (the exploration of Bandung Berkebun garden). In the FAQ document of BdgBerkebun [22], TK Bintang Ceria, TK Irhamna, SD Semi Palar, SD Pardomuan, SD IT Rabbani, and SDN Raya Barat were recorded to have collaboration with this community. Bandung Berkebun also frequently invites students in Bandung to join training, i.e. SMACreatiFarming aiming to increase students' farming skills and their attachment to the nature. This community perceives that education is an effective way to introduce environmental caring behaviour to the community. The existence of farming communities in several countries position themselves to educate citizens to have environmental knowledge, including the importance of producing healthy foods from their own garden [23]. Therefore, the output of this programme is classified into two categories. Firstly, the activity to demonstrate the food sovereignty can be done from the environment. Secondly, the internalisation of willingness to protect the environment and to assert confidence of the achievement.

In this study, the impacts of education, especially those obtained from the implementation of school urban farming became an important topic. The impacts of education bring about transformation in mindsets, development of knowledge, and skills to citizens in pursuing the benefits that can be obtained [24]. According to Table 1, the presence of educational programmes for children shows the provision of environmental knowledge, which is required for the virtue development in the field of environment [25]. Chawla and Chusing [26] suggested such programme as an attempt to develop active citizens, particularly those, who from early age, have the competence and confidence to achieve their goals by working in team. At the next stage, they will be independently and automatically imitate the learning processes that have been obtained during school urban farming programme in the following meetings. Therefore, there will be opportunities for them to promote similar actions to their family and society.

The study of civic virtue was disposed into environmental virtue in which was interpreted by Sandler [27] as the caring for living beings, the appreciation towards the genuineness of nature, and the moderation in using resources which become the example of environmentally justified virtue. A virtue is considered an environmentally responsive virtue if a character perfectly operates several aspects of natural conservation, such as curiosity about conservation, animal caring, and restrictions on excessive use of resources. In addition, Sandler also mentioned environmentally productive virtues in the form of ecological sensitivity through the manifestation of gratitude and appreciation to the nature, the promotion of environmental caring values, and the provision of advocacy to enhance environmental carrying capacity [27]. On the contrary, apathy and consumptive behaviours are classified as ecological crime. In addition, the World Wide Fund and Nature (WWF) Malaysia in 2008 described that environmental virtue is composed of environmental knowledge, environmental skills, and environmental participation aspects.

Environmental knowledge is an expression of experience and knowledge related to natural interaction and understanding required to create and promote the environmental sustainability, both for individual, group and organization [28]. Ecological awareness can be examined from the observation results showing kindergarten children who can distinguish the types of vegetables and flowers. In addition, they understand that plants live and have needs similar to human, such as water, fertilizer, and sunlight. In primary school-aged children, their knowledge is not limited to the knowledge of the plant only, but also the understanding of good relationships between human beings and their environment will create a carrying capacity for life. Hence, they will have consciousness for not damaging their environment by doing simple things such as not littering or picking plants carelessly. Even the direct practice of farming as an activity of School Urban Farming provides reinforcement for their environmental skills. These findings confirmed the research reported by Pe'er [29] that children with environmental awareness have better environmental ethics than other children.

Environmental skills are skills required to identify, anticipate, prevent, and solve environmental problems, either individually, in group, or organization [28]. Such skills are presented by the mentors of school urban farming by providing knowledge to kindergarten children through stories and images of environmental destructive behaviours or so-called "environmental harm". In higher level of primary school, the students are given the understanding of the environmental harm impacts associated with the ecological cycle as the subject of science that has been learned in formal school. Essentially, they can identify environmental issues in Bandung city, including 
river pollution, air pollution, and waste disposal as well as the efforts to minimize the adverse effects of the situation. It eventually raises a sense of belonging that begins with a sense of disinclination to damage their gardens and subsequently, their neighbourhood. From the environmental knowledge and environmental skills, the motivation and various actions to create a sustainable environment, both individually, in group or organization (environmental participation) are advocated.

The effects of urban farming programme in Bandung also occurred in Tehran City, Iran. Urban Agriculture programme in Tehran becomes a positive movement for the empowerment of women, students and the general public through the development of decision-making and education [30]. In Adelaide, Urban Ecology Australia Inc. (UEA), established in 1991, has been a popular non-profit community in the environmental field. The UEA also has educational objectives, which is providing ecological information and facilities in collaboration with citizens, lecturers, journalists, and participants from various fields [31]. Therefore, this programme can be a model of environmental education that is effectively implemented in a non-formal level. This environmental education does not only obtain ecological benefits but also virtue development of the citizens who are more concerned about the environment, particularly those targeting formal school children through school urban farming programme. Farming methods in schools or the neighbourhood can be used as supporting activities that convey the Environmental Education (PLH) learning process. Organic farming programmes in schools are proven to improve the value orientation of the environment which further encourages the rise of environmentally significant behaviour or ESB [32]. ESB is embodied from the desire or attitude to help, share, and work together that is known as pro-social behaviour. The manifestation of ESB in environmental psychology study is the construction of value orientation, beliefs, and personal norms. In urban farming school, most activities are highlighted on raising the participants' awareness to the problems that exist in their surrounding in order to construct beliefs. The reasons expressed concerning a behaviour, either pro-environmental behaviour or environmental crime will reflect the value orientation of the participants. In the processing cycle, participants are encouraged and convinced that they have the perceived ability to reduce the threat to the environment. Specifically, in the core activities of farming, participants are given moral responsibility to take care of the garden. This process also involves other habits supporting the success of the farming process. It leads to personal norms in the form of moral responsibility to perform specific action [32].

The development of a school culture that improves environmental caring character can be achieved by school urban farming programme. It is initiated by Bandung Berkebun community through collaboration with schools. The development of school culture to improve environmental caring character through such programme still requires the participation of teachers, parents, and social community [33]. Learning through farming practices as incorporated in this programme is suitable to provide opportunities for children in developing characteristic values related to environmental awareness [34]. This kind of activity becomes a model of character building that interprets the value of environmental awareness in the formal domain to young citizens in order to become civilized human. Dewi and Budimansyah [35] claimed this model as an interceptive education, namely a process of formal character education put into learning interactions with a structured goal to attain the development of environmental care.

Environmental ethics in a variety of pro-environmental movements is the definition of humans' main character respecting the interaction and relationship with the environment [27]. Rolston in [36] defined environmental ethics as humans' obligation to respect the nature, to have responsibility for the nature through the optimization of human roles on the Earth. Based on the context of civic theory, this responsibility is seen as the embodiment of civic virtue in the environmental field. It is corroborated by the understanding that citizenship status continues to be in relation with environmental obligations [37,38]. Dobson [19] introduced the term ecological citizenship as the realization of habituation practice for the virtue internalization, such as care and compassion. From the perspective of Civic Education, this term is in accordance with the main goal of citizenship education, which is not attached to the formal curriculum content but more to the citizenship practice. In Civic Education perspective, citizen participation is constructed by elements resembling the aspects of environmental virtue, namely the development of civic knowledge, civic virtue, civic skills, civic disposition, and civic commitment [39] to build smart and good citizen.

Budimansyah and Suryadi [40] also mentioned that Civic Education paradigm proposed by international community and a number of centres for Civic Education also accentuates the maturity of civic virtue and civic culture. The degradation of civic virtue in the context of environment is indicated by the massive forest demolition, such as illegal logging, irresponsible pile-up of garbage and industrial waste, as well as declining air and water quality. A situation in which children are completely unaware of their role as citizen so that a voluntary group programme to involve children's active participation is needed [41]. School urban farming can be classified as part of a voluntary group in which knowledge, skills and ethics are demonstrated in the citizens participation in the form of proenvironment activities as environmental care realisation. This programme proves to develop commitment, self-efficacy, and competence of young citizens leading to civic virtue actualised through a series of ecological sustainability efforts [42,43]. Bandura suggested self-efficacy instilled in children is the actualization of self-efficacy as a belief to motivate oneself based on the experience obtained [44]. Environmental education to children can promote environmental awareness derived from the accumulation of knowledge and skills so as to construct a positive value on the awareness of environmental phenomenon and the processes within it [45]. It can be claimed that citizenship virtue is obtained since this programme builds intellectual, skills and affective intelligence in children as they directly participate in environmental conservation efforts. 


\section{CONCLUSION}

This study revealed the development of environmental virtue fostered through environmental education driven by a bottom-up movement within social community. The contribution of voluntary group in providing environmental value education for children indicates that the enculturation of particular virtue in citizen candidates can be done through a series of knowledge, skills and characteristics. Various experiences in school urban farming programme have promoted value orientation, beliefs, and self-norms in themselves so as to have environmentally productive virtues as well as ecological sensitivity in perceiving environmental issues. The strategy has been formulated and the system is available. The challenge ahead is the determined willingness to make changes associated with the deterioration of the ecological condition.

\section{ACKNOWLEDGEMENT}

Thanks to every member of Bandung Berkebun community who are willing to take the researcher as a member to conduct this study. In addition, thanks to every participant of school urban farming, parents, and teachers for the hospitality and assistance during data collection process. Last, this paper would not be completed on time without the permission given by Department of Agriculture and Food Security in Bandung.

\section{REFERENCES}

[1] Nagra, V. Environmental education awareness among school teachers. Enviromentalist, 30, 2010. pp. 153-162.

[2] Pauw, J. B., and Petegem, P. V. A cross-cultural study of environmental values and their effect on the environmental behavior of children. Environment and Behavior, 45(5), pp. 551-583. 2011.

[3] Shelton, D. L. Human rights and the environment: Substantive rights. GW Legal Research Paper No. 2013-33, 265. Available at: http://scholarship.law.gwu.edu/cgi/viewcontent.cgi? article $1 / 41242$ andcontext $1 / 4$ faculty_publications. 2011.

[4] Loram, A., Urban domestic gardens: The effects of human interventions on garden composition. Environmental Management, 48, pp. 808-824. (2011).

[5] Barthel, S., Parker, J. dan Ernstson, H. Food and green space in cities: A resilience lens on gardens and urban environmental movements. Urban Studies, 52 (7), pp. 1321-1338. 2015.

[6] Gallaher, C. M., Urban agriculture, social capital, and food security in the Kibera slums of Nairobi, Kenya. Agric Hum Values, 30, pp. 389404. 2013.

[7] Carney, P. A., Impact of a community gardening project on vegetable intake, food security and family relationships: A community-based participatory research study. Community Health, 37, pp. 874-881. 2011.

[8] Galhena, D. H., Home gardens: a promising approach to enhance household food security and wellbeing. Agriculture and Food Security, pp. 1-13. 2013.

[9] Specht, K., Urban agriculture of the future: an overview of sustainability aspects of food production in and on buildings. Agric Hum Values, 31, pp. 33-51. 2014.

[10] Fifolt, M., Promoting school connectedness among minority youth through experience-based urban farming. Journal of Experiential Education, pp. 1-17, 2017.

[11] Ratcliffe M. M, The effects of school garden experiences on middle school-aged students' knowledge, attitudes, and behaviours associated with vegetable consumption. Health Promotion Practice, 12(1): 36-43. 2011.

[12] Sonti, N. F, Long-term outcomes of an urban farming internship program. Journal of Experiential Education, Vol. 39(3), pp. 269 -287. 2016.

[13] Wuryandari, Politik Luar Negeri Indonesia dan Isu Lingkungan Hidup. Yogyakarta: Lembaga Ilmu Pengetahuan Indonesia. 2015.

[14] Certoma, C. and Notteboom, B. Informal planning in a transactive governmentality: Re-reading planning practices through Ghent's community gardens. Planning Theory, pp. 1-24. 2015.

[15] McCarney, P. L. City indicators on climate change implications for governance. Environment and Urbanization ASIA, 3 (1), pp. 1-39. 2012.

[16] Fraenkel, J., How to design and evaluate research in education. 8th Edition. New York: McGraw-Hill. 2012.

[17] Shneerson, C. L., and Gale, N. K. Using mixed methods to identify and answer clinically relevant research questions. Qualitative Health Research, pp. 1-12. 2015.

[18] Miles, M. B. and Huberman, A. M. Analisis data kualitatif: Buku sumber tentang metode-metode baru. Jakarta: Universitas Indonesia Press. 2012.

[19] Dobson, A. Environmental citizenship: towards sustainable development. Sustainable Development, 15, pp. 276-285. 2007.

[20] Escrihuela, C. M. Promoting ecological citizenship: Rights, duties and political agency. ACME: An International E-Journal for Critical Geographies, 7 (2), 113-134. 2008.

[21] Sudjana, H. D. Pendidikan nonformal: wawasan, sejarah perkembangan, filsafat, teori pendukung, asa. Bandung: Falah Prodution. 2010.

[22] Bandung Berkebun. Frequently asked question BdgBerkebun. Bandung: unpublished. 2014.

[23] Lautenschlager, L. and Smith, C. Beliefs, knowledge, and values held by inner-city youth about gardening, nutrition, and cooking. Agriculture and Human Values, 24, pp. 245-258. 2007.

[24] Okvat, H. A. and Zautra, A. J. Community gardening: A parsimonious path to individual, community, and environmental resilience. Am J Community Psychol, 47, pp. 374-387. 2011.

[25] Prasetiyo, W. H. and Budimansyah, D. Warga negara dan ekologi: Studi kasus pengembangan warga negara peduli lingkungan dalam komunitas bandung berkebun. Jurnal Pendidikan Humaniora, Vol. 4 No. 4, pp. 177 186. 2016.

[26] Chawla, L., and Cushing, D. F. Education for strategic environmental behavior. Environmental Education Research, Vol. 13, No. 4, September 2007, pp. 437-452. 2007.

[27] Sandler, R. L. Environmental virtue ethics. Lanham, MD: Rowman and Littlefield. 2005.

[28] World Wide Fund and Nature (WWF) Malaysia. Environmental citizenship: Emerging perspectives in Malaysia. Available at: http://awsassets.wwf.org.my/downloads/environmental_citizenship_stud y_report_170510.pdf, 2008.

[29] Pe'er, S., Environmental literacy in teacher training: Attitudes, knowledge, and environmental behavior of beginning students. The Journal of Environmental Education, 39:1, pp. 45-59. 2010.

[30] Amirtahmasebi, R. Food urbanism : Urban agriculture as a strategy to facilitate social mobility in informal settlement. (Thesis). Massachusetts Institute of Technology, Massachusetts. 2008.

[31] Downtown, P. F. Ecopolis: Architecture and cities for a changing climate. Collingwood: CSIRO Publishing. 2002.

[32] Guntur, L. R. Program berkebun sayur organik untuk meningkatkan environmentally significant behavior (ESB) berlandaskan value orientation pada anak usia sekolah dasar. (Thesis). Program Pacasarjana Universitas Padjajaran, Bandung. 2015.

[33] Samong, F., The development of character education in primary schools through the enhancement of school culture. 1st UPI International Conference on Sociology Education, pp. 77-79. 2015.

[34] Sulastri, Implementing value clarification technique to improve environmental awareness among pre-service chemistry teacher. 1st UPI International Conference on Sociology Education, pp. 190-193. 2015. 
[35] Dewi, P. F., and Budimansyah, D. The community-based value education to develop environmental awareness characters for elementary school students. 1st UPI International Conference on Sociology Education, pp. 102-106. 2015.

[36] Sadler-Smith, E. Communicating climate change risk and enabling proenvironmental behavioral change through human resource development, Advances in Developing Human Resources, 17 (4), pp. 442-459. 2015.

[37] Turner, B. S. The erosion of citizenship. British Journal of Sociology, 52, pp. 189-209. 2001

[38] Saiz, A. V. Globalisation, cosmopolitanism and ecological citizenship. Environmental Politics, 14 (2), pp. 163-178. 2005.

[39] Branson, M. S. and Quigley, C. N. The role of civic education. Washinton: Center for Civic Education. 1998.

[40] Budimansyah, D. and Suryadi, K. PKn dan masyarakat multikultural. Bandung : Program Studi Pendidikan Kewarganegaraan. 2008.

[41] Miranda, D., Young citizens participation: Empirical testing of a conceptual model. Youth and Society, pp. 1-21. 2017.
[42] Winataputra, U. S. Pendidikan kewarganegaraan dalam perspektif pendidikan untuk mencerdaskan kehidupan bangsa: gagasan, instrumentasi, dan praksis. Bandung: Widya Aksara Press. 2012.

[43] Quigley, C. N., Civitas: A framework for civic education. Calabas: Center for Civic Education. 1991.

[44] Tabernero, C. and Hernandes, B. Self-efficacy and intrinsic motivation guiding environmental behavior. Environment and Behavior 43(5), pp. 658-675. 2011.

[45] D’Souza, D. Comparing efficacy of instructional approaches to develop environmental awareness among school students. SAGE Open, OctoberDecember 2014 I-8. 2014 